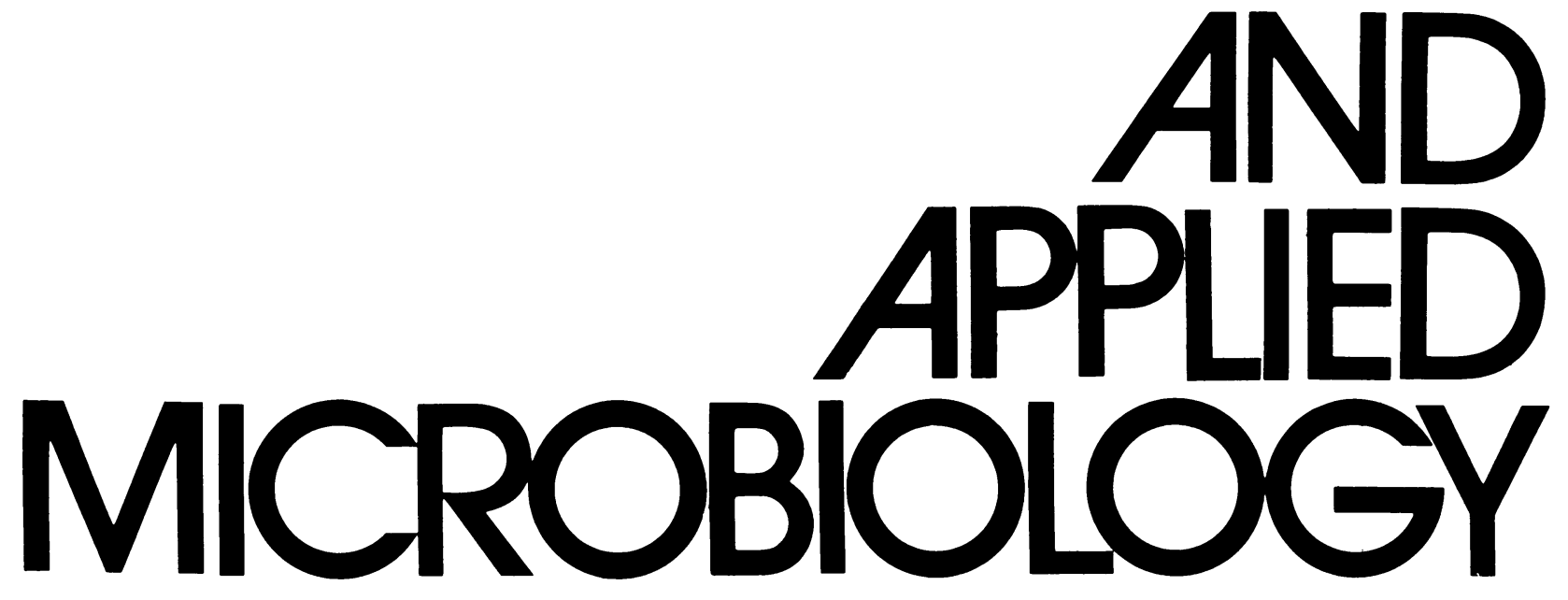

formerly Zentralblatt für Bakteriologie, Mikrobiologie und Hygiene

I. Abt. Originale C

Gustav Fischer Verlag
Stuttgart - New York 
. 


\section{References}

Balch, W. E., Wolfe, R. S.: New approach to the cultivation of methanogenic bacteria: 2-mercaptoethanesulfonic acid (HSCoM)-dependent growth of Methanobacterium ruminantium in a pressurized atmosphere. Appl. Environ. Microbiol. 32, 781-791 (1976)

Balch, W. E., Fox, G. E., Magrum, L. J., Woese, C. R., Wolfe, R. S.: Methanogens: Reevaluation of a unique biological group. Microbiol. Rev. 43, 260-296 (1979)

Belkin, S., Wirsen, C. O., Jannach, $H$. W:: A new sulfur-reducing, extremely thermophilic eubacterium from a submarine thermal vent. Appl. Environ. Microbiol. 51, 1180-1185 (1986)

Bligh, E. G., Dyer, W. J.: A rapid method of total lipid extraction and purification. Canad. J. Biochem. Physiol. 37, 911-917 (1959)

Bradley, S. G.: Criteria for definition of Mycobacterium, Norcardia and the rhodochrous complex. Advan. Front. Plant Sci. 28, 349-362 (1971)

Huber, R., Langworthy, T. A., König, H., Thomm, M., Woese, C. R., Sleytr, U. B., Stetter, K. O.: Thermotoga maritima sp. nov. represents a new genus of unique extremely thermophilic eubacteria growing up to $90^{\circ} \mathrm{C}$. Arch. Microbiol. 144, 324-333 (1986)

International Journal of Systematic Bacteriology: Validation of the publication of new names and new combinations previously effectively published outside the IJSB. List. No. 22. Int. J. Bact. 36, 573-576 (1986)

Jannasch, H. W., Huber, R., Belkin, S., Stetter, K. O.: Thermotoga neapolitana sp. nov. of the extremely thermophilic, eubacterial genus Thermotoga. Arch. Microbiol. 150, 103-104 (1988)

Lane, D. J., Pace, B., Olsen, G. J., Stabl, D. A., Sogin, M. L., Pace, N. R.: Rapid determination of $16 \mathrm{~S}$ ribosomal RNA sequences for phylogenetic analysis. Proc. Natl. Acad. Sci. U.S.A. 82, 6955-6959 (1985)

Langworthy, T. A.: Lipids of Thermoplasma. Meth. Enzymol. $88,396-406$ (1982)

Langworthy, T. A., Pond, J. L.: Membranes and lipids of thermophiles, pp. 107-135. In: Thermophiles: general, molecular, and applied microbiology (T. D. Brock, ed.). New York, John Wiley and Sons, Inc. 1986

Langworthy, T. A., Holzer, G., Zeikus, J. G., Tornabene, T. G.: Iso- and anteiso-branched glycerol diethers of the thermophilic anaerobe Thermodesulfotobacterium commune. System. Appl. Microbiol. 4, 1-17 (1983)
Lauerer, G., Kristiansson, J. K., Langworthy, T. A., König, H., Stetter, K. O.: Methanothermus sociabilis sp. nov., a second species within the Methanothermaceae growing at $97^{\circ} \mathrm{C}$. System. Appl. Microbiol. 8, 100-105 (1986)

Lunan, K. D., Sinsheimer, R. L.: A study of the nucleic acid of bacteriophage T7. Virology 2, 455-562 (1956)

Marmur, J., Doty, P.: Determination of the base composition of deoxyribonucleic acid from its thermal denaturation temperature. J. Molec. Biol. 5, 109-118 (1962)

Ouchterlony, Ö.: Diffusion-in-gel methods for immunological analysis II. pp. 30-154. In: Progress in Allergy, Vol. 6 (P. Kallod, B. H. Waksman, eds.) Karger, Basel 1962

Oyaizu, H., Debrunner-Vossbrinck, B., Mandelco, L., Studier, J. $A$., Woese, C. R.: The green non-sulfur bacteria: a deep branching in the eubacterial line of descent. System. Appl. Microbiol. 9, 47-53 (1986)

Rachel, R., Wildhaber, J., Stetter, K. O., Baumeister, W.: The structure of the surface protein of Thermotoga maritima, pp. 83-86. In: Proceedings of the second international workshop on S-layers in procaryotes (U. B. Sleytr, P. Messner, D. Pum, M. Sara, eds.). Berlin-Heidelberg, Springer-Verlag 1988

Stetter, K. O.: Ultrathin mycelia-forming organisms from submarine volcanic areas having an optimum growth temperature of $105^{\circ} \mathrm{C}$. Nature $300,258-260$ (1982)

Stetter, K. O., Thomm, M., Winter, J., Wildgruber, G., Huber, H., Zillig, W., Janecovic, D., König, H., Palm, P., Wunderl, S.: Methanothermus fervidus, sp. nov., a novel extremely thermophilic methanogen isolated from an Icelandic hot spring. Zbl. Bakt. Hyg., I. Abt. Orig. C 2, 166-178 (1981)

Sueoka, N.: Variation and heterogeneity of base composition of deoxyribonucleic acids: A compilation of old and new data. J. Molec. Biol. 3, 31-40 (1961)

Volkin, E., Astrachan, L., Countryman, J. L.: Metabolism of RNA phosphorus in Escherichia coli infected with bacteriophage T7. Virology 6, 545-555 (1958)

Windberger, E., Huber, R., Trincone, A., Fricke, H., Stetter, K. O.: Thermotoga thermarum sp. nov. and Thermotoga neapolitana occurring in African continental solfataric springs. Arch. Microbiol. 151, 506-512 (1989)

Woese, C. R.: Bacterial evolution. Microbiol. Rev. 51, 221-271 (1987)

Zillig, W., Stetter, K. O., Wunderl, S., Schulz, W., Priess, H., Scholz, I.: The Sulfolobus- "Caldariella" group: Taxonomy on the basis of the structure of DNA-dependent RNA polymerases. Arch. Microbiol. 125, 259-269 (1980)

Professor Dr. Karl O. Stetter, Lehrstuhl für Mikrobiologie, Universität Regensburg, Universitätsstr. 31, D-8400 Regensburg 


\title{
Metallosphaera sedula gen. and sp. nov. Represents a New Genus of Aerobic, Metal-Mobilizing, Thermoacidophilic Archaebacteria
}

\author{
GERTRUD HUBER $^{1}$, CAROLA SPINNLER ${ }^{1}$, AGATA GAMBACORTA $^{2}$, and KARL O.STETTER ${ }^{1}$ \\ 1 Lehrstuhl für Mikrobiologie der Universität Regensburg, 8400 Regensburg, Federal Republic of Germany \\ 2 Istituto per la Chimica di Molecole di Interesse Biologico, Via Toiano 6, 80072 Arco Felice Naples, Italy
}

Received April 18, 1989

\section{Summary}

From a solfataric field in Italy three isolates of spherical thermoacidophilic metal-mobilizing archaebacteria were obtained. They are facultative autotrophs. From sulfidic ores they extract metal ions with very high efficiency. They are also vigorous $S^{\circ}$-oxidizers. Alternatively, they are able to use heterogeneous organic material such as yeast extract. The isolates grow within a temperature range from 50 to $80^{\circ} \mathrm{C}$. The GC-content of their DNA is $45 \mathrm{~mol} \%$. No significant DNA homology is detectable between the isolates and the type strains of the members of the genera Acidianus and Sulfolobus. The DNA-dependent RNA polymerase of isolate TH2 shows incomplete serological cross-reaction with antibodies against the enzyme of Sulfolobus acidocaldarius. On the basis of the distinct physiological and molecular properties we describe the new strains as members of the new genus Metallosphaera. Type species and type strain is Metallosphaera sedula (TH2, DSM5348).

Key words: Metallosphaera - Sulfolobaceae - Archaebacteria - Leaching - Acidophilic - Chemolithotroph - Thermophilic

\section{Introduction}

Organisms able to extract metal ions from sulfidic ores ("bioleaching") are known within eu- and archaebacteria. The eubacterial metal-mobilizers are the mesophilic acidophilic species Thiobacillus ferrooxidans (Colmer and Hinkle, 1947), Thiobacillus prosperus (Huber and Stetter, 1989), and Leptospirillum ferrooxidans (Balashova et al., 1974). Within the archaebacteria (Woese et al., 1978), a thermophilic species capable of mobilizing metal ions is known (Brierley and Murr, 1973). It has been isolated from a thermal spring drainage in Yellowstone National Park (Brierley and Brierley, 1973). Brierley's isolate grows at temperatures up to $75^{\circ} \mathrm{C}$, within a $\mathrm{pH}$ range from 1 to 6 (Segerer et al., 1986), and is able to use elemental sulfur, ferrous iron, sulfidic ores, yeast extract, tryptone and casamino acids as energy sources (Brierley and Brierley, 1973; Brierley and Murr, 1973; C. Brierley, pers. comm.; Zillig et al., 1980; Segerer et al., 1986). Mainly on the basis of its similar morphology and its serologically crossreacting RNA polymerase, Brierley's isolate was described as Sulfolobus brierleyi (Zillig et al., 1980). Further investigations demonstrated that $S$. brierleyi was a facultative anaerobe. Like Acidianus infernus it was capable of grow- ing anaerobically by lithoautotrophic sulfur reduction. Since both organisms exhibited the same GC-content, it became evident that $S$. brierleyi belonged to the genus Acidianus. It has therefore been transferred to this genus and described as Acidianus brierleyi (Segerer et al., 1986). Two further coccoid isolates were reported to be able to extract metal ions from sulfidic ores at temperatures up to $75{ }^{\circ} \mathrm{C}$ (Marsh et al., 1983). However, their physiological features as well as their phylogenetic position remain unclear.

In this paper we describe the isolation and properties of three novel strains of metal-mobilizing archaebacteria belonging to an up to now unknown genus.

\section{Materials and Methods}

Strains. The type strains of Sulfolobus acidocaldarius (DSM 639), Sulfolobus solfataricus (DSM 1616) and Acidianus brierleyi (DSM 1651) were obtained from the Deutsche Sammlung von Mikroorganismen und Zellkulturen (DSM, Braunschweig, FRG). Acidianus infernus (DSM 3191) was isolated in our laboratory (Segerer et al., 1986). 
Culture conditions. For the cultivation of the new isolates and the type strains the medium of Allen (1959) modified by Brock et al. (1972) was used. The $\mathrm{pH}$ was adjusted to 2.0 with $10 \mathrm{~N}$ $\mathrm{H}_{2} \mathrm{SO}_{4}$. On sulfur or soluble substrates the organisms were grown in test-tubes $(270 \times 18 \mathrm{~mm} ; 20 \mathrm{ml}$ medium), on ores in $100 \mathrm{ml}$ Erlenmeyer flasks $(30 \mathrm{ml}$ medium). The new isolates were routinely cultivated on the ore mixture "G6" ( $1 \mathrm{~g} / 30 \mathrm{ml}$ medium) consisting of equal parts of pyrite (Grube Bayerland, Oberpfalz), sphalerite (Grube Lüderich, Nordrhein-Westfalen) and pitch blend (Grube Höhenstein, Oberpfalz). Leaching experiments were carried out with ore mixture "G1N" which contained the three components of "G6" and, in addition, chalcopyrite from Norway (each $25 \%$ w/w).

Chemical composition of the ore mixture "G1N" ( $1 \mathrm{~g}$ dissolved in $30 \mathrm{ml}$ aqua regia):

$\begin{array}{lrlllll}\text { As } & 58 \mathrm{ppm} ; \mathrm{Fe} & 6800 \mathrm{ppm} ; \mathrm{Pb} & 250 \mathrm{ppm} ; \mathrm{Y} & 2 \mathrm{ppm} ; \\ \mathrm{Cd} & 12 \mathrm{ppm} ; \mathrm{Ge} & 30 \mathrm{ppm} ; \mathrm{Th} & 4 \mathrm{ppm} ; \mathrm{Yb} & 4 \mathrm{ppm} ; \\ \mathrm{Co} & 10 \mathrm{ppm} ; \mathrm{Hg} & 13 \mathrm{ppm} ; \mathrm{Ti} & 2 \mathrm{ppm} ; \mathrm{Zn} & 4500 \mathrm{ppm} ; \\ \mathrm{Cu} & 800 \mathrm{ppm} ; \mathrm{Mn} & 26 \mathrm{ppm} ; \mathrm{U} & 95 \mathrm{ppm} ; \mathrm{Zr} & 3 \mathrm{ppm} ;\end{array}$

Antimony, cerium, chromium, gold, molybdenum, nickel, silver, tin and vanadium were not found in detectable amounts.

For large scale preparations the strains were grown in 851 enamel-protected fermentors (HTE, Bioengineering, Wald, Switzerland) under stirring (150 rev/min) and slightly gassing with compressed air $(25 \mathrm{ml} / \mathrm{min})$. The cells were harvested in the exponential growth phase with a separator (Westfalia, West Germany).

Bacterial growth. Cell concentrations were determined with a Zeiss Standard 16 microscope by direct counting in a Thoma counting chamber (depth $0.02 \mathrm{~mm}$ ). For the visualization of cells on solid particles they were stained by a modified "DAPI" (4'-6'Diamidino-2-phenylindole) procedure (Huber et al., 1985) and observed with the fluorescence equipment IV FL with an excitation filter BP 365 and a selection filter LP 420.

Electron microscopy. Electron microscopy was performed as described previously (Huber and Stetter, 1989).

Substrate utilization. For heterotrophic growth one of the following organic substances was added to the mineral medium (10 $\mathrm{g} /$ ): yeast extract, tryptone, casamino acids (all: Difco); peptone, beef extract, $\mathrm{L}-(+)$-arabinose, $\mathrm{D}-(-)$-fructose, $\mathrm{D}-(+)$-galactose, $\mathrm{D}-(+)$-glucose, lactose, D- $(+)$-mannose, raffinose, $\mathrm{D}-(-)$-ribose, sucrose, L-(-)-sorbose, D- $(+)$-xylose (all: Merck). In the presence of sulfur $(10 \mathrm{~g} /$ ) or ores, the concentration of yeast extract was reduced to $0.2 \mathrm{~g} /$. In order to determine the inorganic energy sources the following compounds were used: elemental sulfur (Aldrich Chemical Company, Inc.; 99.999\%; $10 \mathrm{~g} / 1$ ), synthetic sulfides (CdS, CuS, FeS, $\mathrm{MoS}_{2}, \mathrm{Sb}_{2} \mathrm{~S}_{3}, \mathrm{SnS}, \mathrm{ZnS}$; each $0.5 \mathrm{~g} / 30 \mathrm{ml}$ ) and natural ores (each $0.5 \mathrm{~g} / 30 \mathrm{ml}$ ):

\section{- arsenopyrite:}

- bornite:

- cinnabar:

- chalcopyrite:

- chalcocite:

- covellite:

- galena:

- pitch blend:

- pyrite:

- sphalerite:
St. Andreasberg (Germany), Haute Loire (France), Reichenstein (Poland)

Butte (Montana, USA), Hasborn (Germany)

Almaden (Spain)

Norway, Cornwall (GB), Kelchalpe (Austria), Kopparberg (Sweden), Tarn (France), Murgul (Turkey) Butte (Montana, USA), Eifel (Germany)

Butte (Montana, USA) Clausthal (Germany)

Grube Höhenstein (Germany) Grube Bayerland (Germany) Grube Lüderich (Germany)
Tolerance against heavy metals. For the examination of the resistance against heavy metal ions, media containing yeast extract or ore mixture "G6" as energy sources were supplemented by the following salts (final heavy metal concentration in $\mathrm{mM}$ ):

$\mathrm{AgNO}_{3} \quad(0.009 ; 0.09 ; 0.9) ; \quad \mathrm{NaAsO}_{2} \quad(0.13 ; 1.3 ; 13)$; $\left(\mathrm{CH}_{3} \mathrm{COO}\right)_{2} \mathrm{Cd} \times 2 \mathrm{H}_{2} \mathrm{O}(0.09 ; 0.9 ; 9) ; \mathrm{CoSO}_{4} \times 7 \mathrm{H}_{2} \mathrm{O}(0.17$ $0.85 ; 1.7) ; \mathrm{CuSO}_{4} \times 5 \mathrm{H}_{2} \mathrm{O}(0.16 ; 1.6 ; 16 ; 79) ; \mathrm{HgSO}_{4}(0.0005 ;$ $0.005 ; 0.05 ; 0.5) ; \mathrm{Na}_{2} \mathrm{MoO}_{4} \times 2 \mathrm{H}_{2} \mathrm{O}(0.01 ; 0.1 ; 1 ; 10) ; \mathrm{SbCl}_{3}$ $(0.08 ; 0.8 ; 8) ;\left(\mathrm{CH}_{3} \mathrm{COO}\right)_{2} \mathrm{UO}_{2} \times 2 \mathrm{H}_{2} \mathrm{O}(0.04 ; 0.4 ; 4) ; \mathrm{ZnSO}_{4}$ $\times 7 \mathrm{H}_{2} \mathrm{O}(15 ; 150 ; 750)$.

Metal analysis. Mobilization of metal ions from the ores was determined by "ICP“ (Inductively Coupled Plasma; JY 70 Plus, Jobin Yvon) analyses of the supernatant from centrifuged culture samples.

Quantitative determination of sulfate. Sulfate was determined gravimetrically as $\mathrm{BaSO}_{4}$ according to Williams (1979). Simultaneously "soluble sulfur" was measured in the supernatant of the cultures by "ICP" analyses (JY 70 Plus, Jobin Yvon).

Lipid analyses. Lipids were extracted from dried cells according to De Rosa et al. (1983 a). The total lipid extract was treated with light petroleum (boiling point $40-70^{\circ} \mathrm{C}$ ). In order to analyze the quinone pattern, the soluble material was chromatographed on thin layer silica plates (TLC; solvent: light petroleum/diethyl ether $95: 5, \mathrm{v} / \mathrm{v}$ ). The insoluble light petroleum fraction contained the complex lipids. They were separated by TLC (solvent: chloroform/methanol/ $\mathrm{H}_{2} \mathrm{O}$ 65:25:4 by vol.) and hydrolyzed in 1 $\mathrm{M}$ methanolic $\mathrm{HCl}$ to cleave the polar head groups. After methanolysis, the different core lipids were separated by TLC with the following solvents (a) 2,3-di-O-phytanyl-sn-glycerol $\left(C_{20,20}\right.$ diether $)$ in chloroform/diethyl ether $95: 5$, v/v; (b) glyceroldialkyl-glycerol tetraethers (GDGTs) in $\mathrm{n}$-hexane/ethyl acetate 7:3, v/v (Trincone et al., 1988); (c) gycerol-dialkyl-nonitol tetraethers (GDNTs) in chloroform/methanol 9:1, v/v (De Rosa et al., 1983 a). Purified samples of caldariellaquinone, sulfolobusquinone, tricyclicquinone (Lanzotti et al., 1986), complex lipids, $\mathrm{C}_{20,20}$ diether, GDGTs and GDNTs from Sulfolobus solfataricus ATCC 49155 were available for comparison by TLC (Lanzotti et al., 1986; De Rosa et al., $1983 \mathrm{a}$; b). All the compounds were detected by exposure to $\mathrm{I}_{2}$ vapour, or by spraying with $0.1 \%$ $\mathrm{Ce}\left(\mathrm{SO}_{4}\right)_{2}$ in $2 \mathrm{~N} \mathrm{H}_{2} \mathrm{SO}_{4}$ reagent, followed by heating at $150^{\circ} \mathrm{C}$ for 5 min. The Dittmer and Lester reagent was used for phospholipids and $\alpha$-naphtol/ $/ \mathrm{H}_{2} \mathrm{SO}_{4}$ for glycolipids.

Preparation of DNA. The DNA was prepared as described previously (Wildgruber et al., 1982).

Determination of the GC-content. The GC-content of the DNA was determined by the $\mathrm{T}_{\mathrm{M}}$-method (Marmur and Doty, 1962) and by high performance liquid chromatography (HPLC) of the nucleotides (Zillig et al., 1980).

DNA-DNA hybridization. DNA-DNA hybridization was carried out according to König (1984).

Purification of DNA-dependent RNA polymerase. The RNA polymerases of $S$.acidocaldarius and of isolate TH2 were prepared by the procedure described by Zillig et al. (1979): (a) treatment with Polymin P, (b) chromatography on DEAE cellulose, (c) chromatography on heparin cellulose, (d) affinity chromatography on calf thymus DNA cellulose and (e) sucrose gradient ultracentrifugation. All steps were carried out in a buffer containing Tris- $\mathrm{HCl}$ (50 mM; pH 7.5), $\mathrm{NH}_{4} \mathrm{Cl}(22 \mathrm{mM})$, EDTA (1 mM), 2 -mercaptoethanol $(10 \mathrm{mM})$ and $10 \%(\mathrm{v} / \mathrm{v})$ glycerol. The activity of the enzymes was determined in a standard assay using poly $[\mathrm{d}(\mathrm{A}-\mathrm{T})]$ as a template.

Polyacrylamide gel electrophoresis. Gel electrophoresis was carried out in a 5-25\% exponential sodium dodecylsulfate polyacrylamide gel (Laemmli, 1970; Mirault and Scherrer, 1971).

Preparation of RNA polymerase antibodies. A rabbit was 
immunized with a total of $180 \mu \mathrm{g}$ of purified RNA polymerase from S.acidocaldarius using a micro method (Stetter, 1977).

Ouchterlony immunodiffusion test. The immunological crossreaction of the antiserum against the RNA polymerase of $S$.acidocaldarius was assayed in the immunodiffusion test of $\mathrm{Ouch}$ terlony (1962).

\section{Results \\ Isolation}

Six aerobic samples of water, sediments and greyish mud were taken from an acidic drain from a hot water pond at Pisciarelli Solfatara (near Naples, Italy). The original temperatures were between 25 and $52^{\circ} \mathrm{C}$ and the $\mathrm{pH}$ was around 2 . The sediments consisted of whitish gravel covered with orange-, red-, or yellow-coloured layers at the surface. These coats contained mainly iron compounds like magnetite or hematite (D. Rose, pers. comm.). All samples were carried to the laboratory without $\mathrm{pH}$ - and temperature-control. The modified mineral medium of Allen (Allen, 1959; Brock et al., 1972) containing pyrite, chalcopyrite or the ore mixture "G1N" as sole energy source was inoculated with each $1 \mathrm{ml}$ of these samples. The enrichment cultures were incubated at $65^{\circ} \mathrm{C}$ under shaking. After one week, spherical cells became visible in two (TH2 and TH4) of the six culture attempts. The enrichment cultures were purified by repeated serial dilutions in the mineral medium containing pyrite $(\mathrm{TH} 2)$ or "G1N" (TH4). For the isolates, the same designations as for the samples were used. Another isolate, strain SP3a, enriched and isolated from the same location on a mixture of elemental sulfur and yeast extract, was unable to grow on sulfidic ores when transferred directly from the isolation medium. However, it was capable of adapting during the following procedure (C. Brierley, pers. comm.): (a) incubation in a medium containing elemental sulfur $(1 \%)$, ferrous sulfate $(1 \%)$ and yeast extract $(0.1 \%)$; (b) transfer

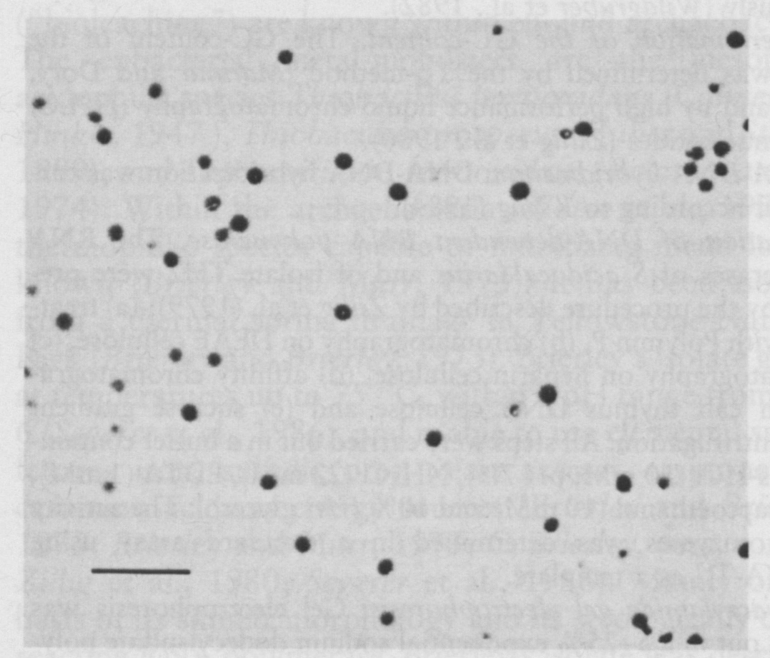

Fig. 1. Phase contrast micrograph of cells of Metallosphaera sedula (isolate $\mathrm{TH} 2$ ). Bar $5 \mu \mathrm{m}$. and incubation in a medium containing ore mixture "G1N" $(3.3 \%)$, ferrous sulfate $(1 \%)$ and yeast extract $(0.005 \%)$; (c) transfer and incubation in a medium containing "G1N" $(3.3 \%)$ and ferrous sulfate $(1 \%)$; (d) transfer and incubation in a medium containing only "G1N" $(3.3 \%)$. The final cell densities were about $8 \times 10^{7} / \mathrm{ml}$ for steps (a) to (c) and $2 \times 10^{8} / \mathrm{ml}$ in the final step (ore mixture alone).

\section{Morphology}

In the phase contrast microscope cells of the three isolates appeared as round to slightly irregular cocci about $1 \mu \mathrm{m}$ in width (Fig. 1). During growth on ores, up to $50 \%$ of the organisms were attached to the particles. In the fluorescence microscope a wiggling of the cells at the ore was observed after visualization by "DAPI" staining (Huber et al., 1985). In the electron microscope pilus-like structures protruding from the cells were detected (Fig. 2). They were about $20 \mathrm{~nm}$ wide and up to $3 \mu \mathrm{m}$ long. These structures were not observed in cultures grown on yeast extract. The cells were Gram-negative. They were surrounded by a cell envelope consisting of protein subunits in regular arrangement (Fig. 3, 4).

\section{Culture and storage}

Cultures grown on ores were routinely transferred into fresh medium after one week ( $5 \%$ inoculum) of incubation. When stored over liquid nitrogen they served as inoculum for at least 18 months. It was not necessary to neutralize or concentrate the grown culture for successful storage.

\section{Growth temperature and $p H$ range}

On ores, isolate $\mathrm{TH} 2$ grew between $\mathrm{pH} 1.0$ and 4.5 (not shown). The optimal growth temperature was around $75^{\circ} \mathrm{C}$ (Fig. 5; doubling time $315 \mathrm{~min}$ ). No growth occurred at $45^{\circ} \mathrm{C}$ and at $85^{\circ} \mathrm{C}$.

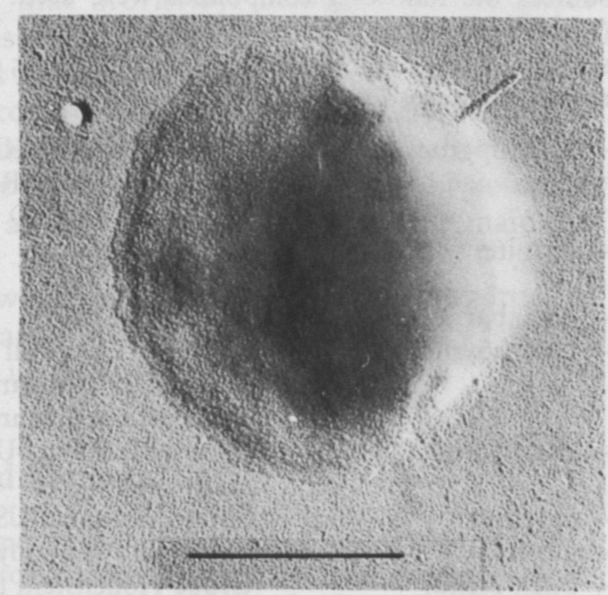

Fig. 2. Electron micrograph of Metallosphaera sedula (isolate TH2), platinum shadowed. Bar $0.5 \mu \mathrm{m}$. 
Fig. 3. Electron micrograph of the cell surface of Metallosphaera sedula (isolate $\mathrm{TH} 2$ ). Bar $0.5 \mu \mathrm{m}$.

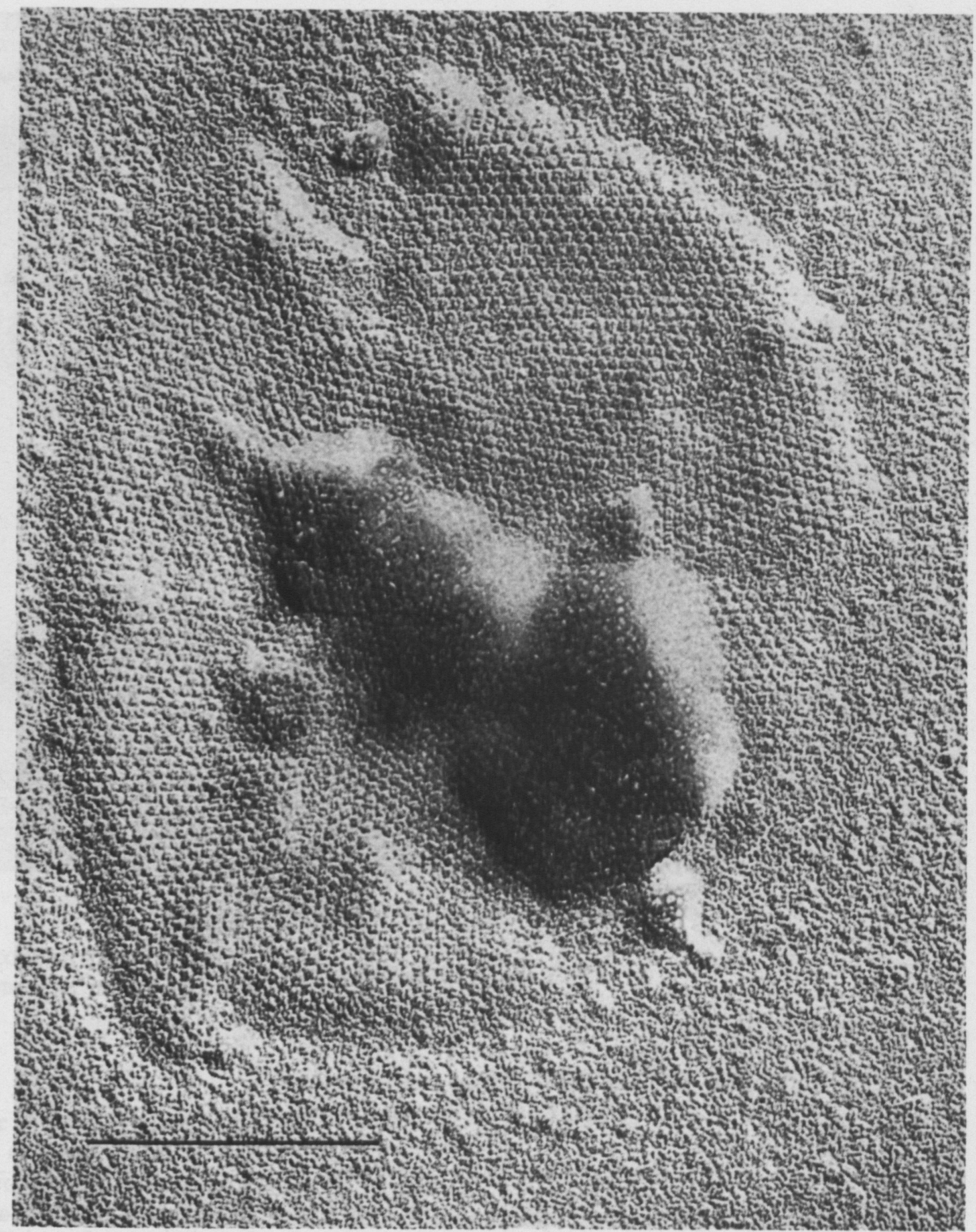

\section{Metabolic properties}

The new isolates grew aerobically on single sulfidic ores like pyrite, chalcopyrite and sphalerite and on combinations of them (ore mixtures "G6" and "G1N"). Growth was also obtained on the synthetic sulfides CdS, SnS and $\mathrm{ZnS}$ and on elemental sulfur. Arsenopyrite, bornite, cinnabar, chalcocite, covellite or galena and the synthetic sulfides $\mathrm{CuS}, \mathrm{FeS}, \mathrm{MoS}_{2}$ and $\mathrm{Sb}_{2} \mathrm{~S}_{3}$ did not serve as substrates. During growth on elemental sulfur, sulfuric acid was formed by the isolate TH2 (final concentration: $45 \mathrm{mM}$ after 20 days; Fig. 6). The presence of yeast extract $(0.005 \%)$ did not change the production rate of sulfate significantly (Fig. 6). The new isolates were able to grow on complex organic substrates such as beef extract, casamino acids, peptone, tryptone and yeast extract. No growth was obtained on sugars.
Under anaerobic conditions in the presence of hydrogen and elemental sulfur, neither growth nor $\mathrm{H}_{2} \mathrm{~S}$ production occurred (A. Segerer, pers. comm.).

\section{Resistance against heavy metal ions}

The resistance of isolate $\mathrm{TH} 2$ against different heavy metal ions was examined during growth on ore mixture "G6" and on yeast extract (Table 1). No differences between autotrophic and heterotrophic cultures were observed for arsenic, cadmium, cobalt, copper, antimony, uranium and zinc ions. Cells grown on ore tolerated higher concentrations of mercury (100 times) and molybdenum (10 times). As a reference Thiobacillus ferrooxidans ATCC 23270 was used. Isolate TH2 showed higher resistance against cadmium and molybdenum. The resistance against arsenic and uranium ions was similar for both 


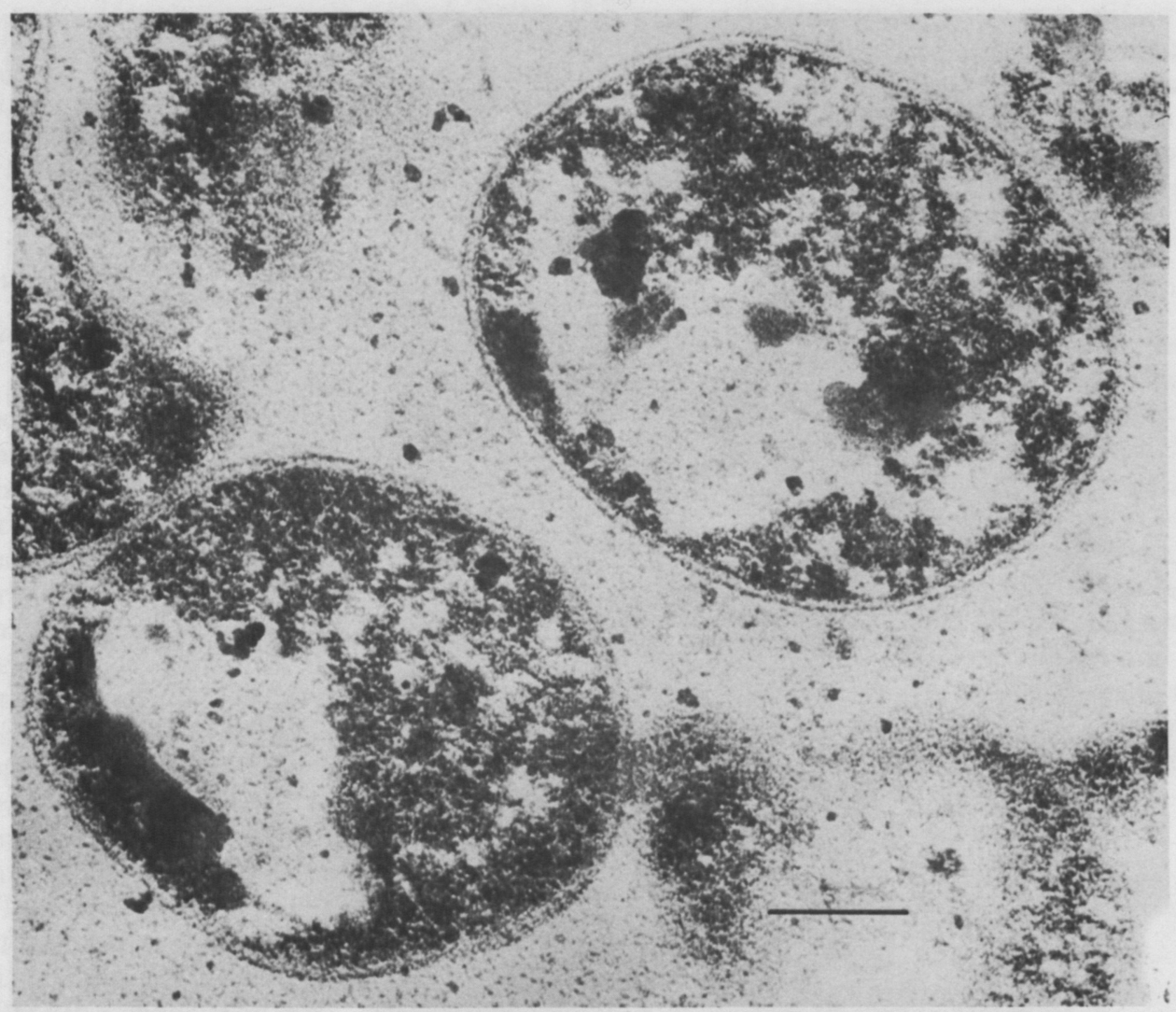

Fig. 4. Thin section of Metallosphaera sedula (isolate TH2) contrasted with lead citrate and uranyl acetate. Bar $0.2 \mu \mathrm{m}$.

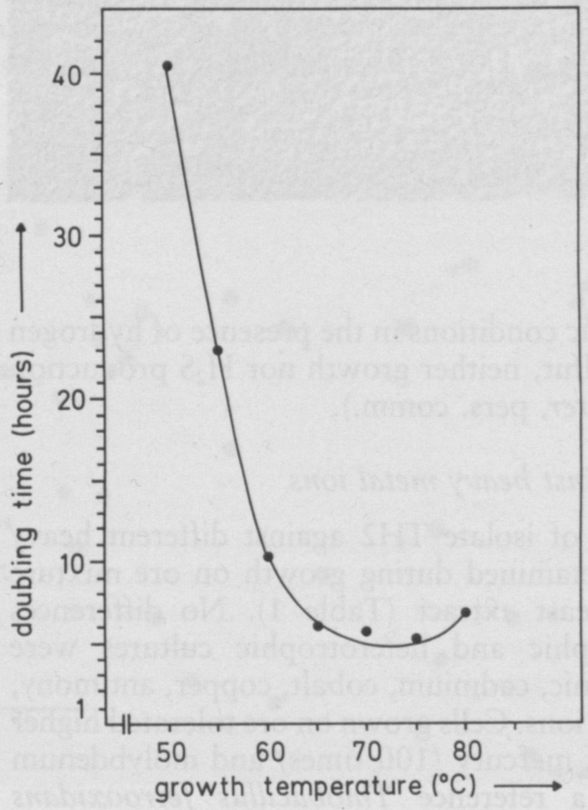

Fig. 5. Optimal growth temperature of Metallosphaera sedula (isolate TH2). The doubling times were calculated from the slopes of the growth curves (not shown).

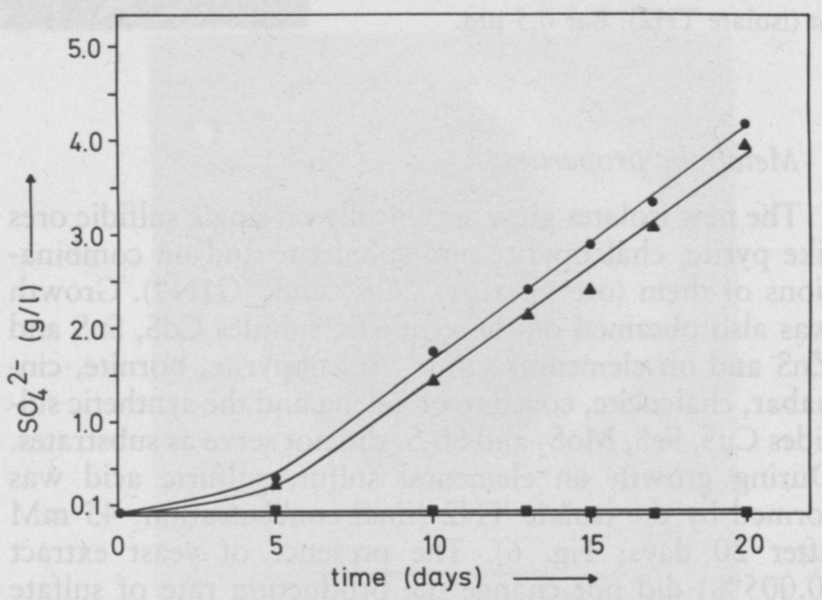

Fig. 6. Sulfate production of Metallosphaera sedula (isolate TH2) during growth on elemental sulfur.

$(-\bullet)$ elemental sulfur; $(\boldsymbol{\Lambda}-\mathbf{\Lambda})$ elemental sulfur and yeast extract $(0.005 \%)$; ( - $)$ medium without substrate. 
Table 1. Tolerances of isolate TH2 and Thiobacillus ferrooxidans against heavy metal ions (mM)

\begin{tabular}{llll}
\hline & Strain & & \\
Metal & TH2 (YE) & TH2 (ore) & T.ferrooxidans* \\
\hline $\mathrm{Ag}$ & & & \\
\hline & n.d. & 0.09 & 0.9 \\
$\mathrm{As}$ & (n.d.) & $(0.9)$ & $($ i.d.) \\
& 1.3 & 1.3 & 1.3 \\
$\mathrm{Cd}$ & $(13)$ & $(13)$ & $(13)$ \\
& 0.9 & 0.9 & 0.09 \\
$\mathrm{Co}$ & $(9)$ & $(9)$ & $(0.9)$ \\
& 0.85 & 0.85 & 17 \\
$\mathrm{Cu}$ & $(1.7)$ & $(1.7)$ & $(85)$ \\
& 16 & 16 & 160 \\
$\mathrm{Hg}$ & $(79)$ & $(79)$ & $(790)$ \\
& 0.0005 & 0.05 & 0.5 \\
$\mathrm{Mo}$ & $(0.005)$ & $(0.5)$ & $($ i.d.) \\
& 0.1 & 1 & 0.1 \\
$\mathrm{Sb}$ & $(1.0)$ & $(10)$ & $(1)$ \\
& 0.8 & 0.8 & 8 \\
$\mathrm{U}$ & $(8)$ & $(8)$ & $($ i.d.) \\
& 0.4 & 0.4 & 0.4 \\
$\mathrm{Zn}$ & $(4)$ & $(4)$ & $(4)$ \\
& 150 & 150 & 750 \\
& $(750)$ & $(750)$ & $(1500)$ \\
\hline
\end{tabular}

n.d. = not determined;

i.d. = impossible to determine due to precipitation;

( ) = concentration of total inhibition;

* Huber and Stetter (1989)

organisms. Against silver, cobalt, copper, mercury, antimony and zinc ions, the new isolate was more sensitive than $T$. ferrooxidans.

\section{Ore leaching capacity}

During growth on the ore mixture "G1N", isolate TH2 mobilized up to $100 \%$ of the total copper, uranium and zinc within 2 to 3 weeks (Table 2). For the Sulfolobus type strains, growth in the presence of ore was only obtained in combination with yeast extract. Within three weeks of incubation, the $\mathrm{pH}$ raised from 2.5 to 5.0. Concomitantly, no microbial metal extraction was evident when compared with the sterile control test (Table 2). As expected, Acidianus brierleyi grew autotrophically on ore mixtures (e.g. "G1N"). However, the final cell concentrations were rather low (about $1 \times 10^{7}$ cells $/ \mathrm{ml}$ ). They were raised about 10 times by the addition of low amounts of yeast extract $(0.02 \%)$. Metal ion extraction continued in the presence of yeast extract (Table 2). Acidianus infernus was also able to grow autotrophically on ore mixtures (not shown), but metal mobilization with or without organic material was rather low (Table 2).

\section{Lipid composition}

The isolates TH2 and SP3a showed a lipid pattern (core and complex lipids) very close to that reported for Sul folobus solfataricus (De Rosa et al., 1983 a, b). However, the relative proportions of glycolipids and minor complex
Table 2. Metal extraction by the new isolates and by the Acidianus and Sulfolobus type strains from the ore mixture "G1N" after 21 days of incubation (mg/l)

\begin{tabular}{|c|c|c|c|c|}
\hline Metal & $\mathrm{Cu}$ & $\mathrm{Fe}$ & $\mathrm{U}$ & $\mathrm{Zn}$ \\
\hline TH2 & 750 & 40 & 90 & 4000 \\
\hline TH4 & 610 & 25 & 90 & 2400 \\
\hline SP3a & 540 & 25 & 85 & 2000 \\
\hline A. brierleyi & 140 & 20 & 80 & 1400 \\
\hline sterile control \# 1 & 45 & 480 & 65 & 800 \\
\hline A. infernus & 10 & 550 & 85 & 1200 \\
\hline sterile control \# 2 & 4 & 300 & 75 & 300 \\
\hline S. acidocaldarius & 1 & 110 & 20 & 170 \\
\hline S. solfataricus & 1 & 100 & 30 & 270 \\
\hline sterile control \# 3 & 1 & 120 & 20 & 260 \\
\hline total amount ${ }^{\circ}$ & 800 & 6800 & 95 & 4500 \\
\hline
\end{tabular}

Sterile controls were carried out under the same $\mathrm{pH}$ and temperature conditions as the corresponding strains:

\# 1: $\mathrm{pH} \mathrm{2.5;} \mathrm{T}=65^{\circ} \mathrm{C}$; \# 2: $\mathrm{pH} \mathrm{2.5;} \mathrm{T}=80^{\circ} \mathrm{C}$; \# 3: $\mathrm{pH} 5 ; \mathrm{T}=$ $65^{\circ} \mathrm{C} ;{ }^{\circ}=$ determined by chemical extraction with concentrated aqua regia. The type strains of Acidianus and Sulfolobus were cultivated in media containing yeast extract $(0.02 \%)$ in addition to the ore mixture "G1N".

lipids were different. Both strains contained essentially caldariellaquinone, which is a typical component of the membrane of $S$. solfataricus (Lanzotti et al., 1986). Sulfolobusquinone and tricyclicquinone were absent (Lanzotti et al., 1986; Thurl et al., 1986).

\section{GC-content of the DNA}

The three isolates TH2, TH4 and SP3a exhibited GCcontents of 45,45 and $44 \mathrm{~mol} \%$ (Table 3). The DNA base composition of the Acidianus and Sulfolobus type strains served as references (Table 3).

\section{Sensitivity to diphtheria toxin}

After addition of diphtheria toxin to the crude extract of isolate TH2, a protein, most likely elongation factor II, was ADP-ribosylated (F. Klink, pers. comm.; Kessel and Klink, 1980).

Table 3. GC-content of the new isolates and of the Acidianus and Sulfolobus type strains

\begin{tabular}{|c|c|c|c|}
\hline \multirow[b]{2}{*}{ Strain } & \multicolumn{3}{|c|}{ GC-content $(\mathrm{mol} \%)$} \\
\hline & $T_{M}$ & $\begin{array}{l}\text { direct } \\
\text { analysis }\end{array}$ & literature \\
\hline TH2 & 44.6 & 46.7 & - \\
\hline TH4 & 44.1 & 46.1 & - \\
\hline SP3a & 43.7 & n.d. & - \\
\hline A. brierleyi & 30.5 & 30.0 & $31^{*}$ \\
\hline A. infernus & 30.5 & 33.0 & $31^{* *}$ \\
\hline S. acidocaldarius & 35.6 & 36.7 & $38^{*}$ \\
\hline S. solfataricus & 34.0 & 33.7 & $35^{*}$ \\
\hline
\end{tabular}

* Zillig et al. (1980); * Segerer et al. (1986); n.d. = not determined. 


\section{DNA homology}

DNA - DNA cross hybridization experiments between the new strains revealed homologies of $94 \%$ and above indicating that they belong to the same species (Table 4). As was expected cultures of isolate $\mathrm{TH} 2$, grown on ores and on yeast extract, were $100 \%$ homologous (within the accuracy of the method; Table 4). No specific relationship of the new organisms could be detected with the Sulfolobus and Acidianus type strains as indicated by insignificant hybridization rates of $12 \%$ and below (Steigerwalt et al., 1976; Schleifer and Stackebrandt, 1983; Table 4).

Table 4. DNA-DNA homologies between the new isolates and the Acidianus and Sulfolobus type strains (in \%)

\begin{tabular}{|c|c|c|c|c|c|c|}
\hline \multirow{2}{*}{$\begin{array}{l}\text { Filter-bound } \\
\text { DNA from }\end{array}$} & \multicolumn{6}{|c|}{${ }^{32} \mathrm{P}$-labelled DNA from } \\
\hline & $\begin{array}{l}\text { A. } \\
\text { brier. }\end{array}$ & $\begin{array}{l}\text { S. } \\
\text { acido. }\end{array}$ & $\begin{array}{l}\text { S. } \\
\text { solf. }\end{array}$ & $\begin{array}{l}\text { TH2 } \\
\text { ore }\end{array}$ & $\begin{array}{l}\text { TH2 } \\
\text { YE }\end{array}$ & $\begin{array}{l}\text { TH4 } \\
\text { YE }\end{array}$ \\
\hline A. brier. & 100 & 5 & 9 & 7 & 10 & n.d. \\
\hline A. infernus & 6 & 3 & 5 & 6 & n.d. & n.d. \\
\hline S. acido. & 4 & 100 & 12 & 12 & n.d. & n.d. \\
\hline S. solf. & 7 & 9 & 100 & 8 & n.d. & n.d. \\
\hline $\mathrm{TH} 2$ ore & 12 & 8 & 10 & 100 & 100 & n.d. \\
\hline TH2 YE & 10 & n.d. & n.d. & 98 & 100 & 94 \\
\hline TH4 YE & n.d. & n.d. & n.d. & n.d. & 97 & 100 \\
\hline
\end{tabular}

n.d. = not determined; YE = yeast extract;

A. brier. $=$ A. brierleyi DSM 1651; S. acido. $=$ S. acidocaldarius DSM 639; S. solf. $=$ S. solfataricus DSM 1616.

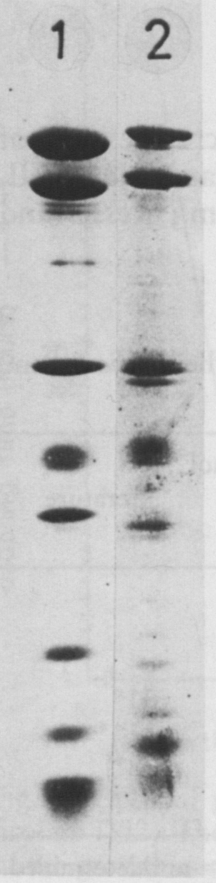

Fig. 7. Subunit patterns of the RNA polymerases after sodium dodecylsulfate polyacrylamide gel electrophoresis.

(1) S. acidocaldarius DSM 639; (2) Metallosphaera sedual (isolate $\mathrm{TH} 2$ ).

\section{DNA-dependent RNA polymerase}

In the sodium dodecylsulfate polyacrylamide gel the DNA-dependent RNA polymerase of isolate TH2 exhibited the "BAC" pattern characteristic for sulfurmetabolizing archaebacteria (Fig. 7; Schnabel et al., 1983). The RNA polymerase of Sulfolobus acidocaldarius was used as molecular weight standard (Prangishvilli et al., 1982). The molecular weights of the subunits of the RNA polymerase of isolate $\mathrm{TH} 2$ were calculated after coelectrophoresis with the $S$. acidocaldarius enzyme (Table 5). It consisted of two heavy subunits (130 and $104 \mathrm{kD})$ and 9 light polypetide chains with molecular weights between 42 and $11.3 \mathrm{kD}$. In the Ouchterlony immunodiffusion test (Fig. 8), antibodies prepared against the purified RNA polymerase of S.acidocaldarius yielded an incomplete cross-reaction with the enzyme of isolate $\mathrm{TH} 2$ and with the enriched RNA polymerases of S.solfataricus and A. brierleyi. As was expected, no serological cross-reaction with a member of the Thermoproteales, Pyrobaculum islandicum, was obtained (not shown).

Table 5. Molecular weights (in kilodaltons) of components of the DNA-dependent RNA polymerases of Sulfolobus acidocaldarius and Metallosphaera sedula (isolate $\mathrm{TH} 2$ )

\begin{tabular}{lll}
\hline Subunit* & $\begin{array}{c}\text { Strain } \\
\text { Sulfolobus } \\
\text { acidocaldarius }\end{array}$ & $\begin{array}{l}\text { Metallosphaera } \\
\text { sedula }\end{array}$ \\
\hline B & 122 & 130 \\
A & 101 & 104 \\
C & 44 & 42 \\
$\mathrm{D}_{1}$ & 33 & 33.5 \\
$\mathrm{D}_{2}$ & 32 & 32 \\
$\mathrm{E}$ & 26 & 24.5 \\
$\mathrm{~F}$ & 17.5 & 15.8 \\
$\mathrm{G}$ & 13.8 & 14.5 \\
$\mathrm{H}$ & 11.8 & 13 \\
$\mathrm{I}$ & 11.2 & 11.8 \\
$\mathrm{~J}$ & 10.8 & 11.3 \\
\hline
\end{tabular}

- Molecular weights according to Prangishvilli et al. (1982)

* Designations in analogy to S. acidocaldarius following the molecular sizes.

\section{Discussion}

The three new isolates $\mathrm{TH} 2, \mathrm{TH} 4$ and $\mathrm{SP} 3 \mathrm{a}$ are spherical to slightly irregular thermophilic organisms able to extract metal ions from sulfidic ores. They belong to the archaebacterial kingdom (Woese et al., 1978) as demonstrated by the occurrence of isopranyl ether lipids (De Rosa et al., 1977; Langworthy et al., 1982; De Rosa and Gambacorta, 1988), the presence of an ADP-ribosylable elongation factor II-like protein (Kessel and Klink, 1982), and the complex structure of the DNA-dependent RNA polymerase (Zillig et al., 1980; Zillig et al., 1982). By their acidophilic mode of life and the presence of benzothiophenquinone and glycerol-dialkyl-nonitol tetra- 


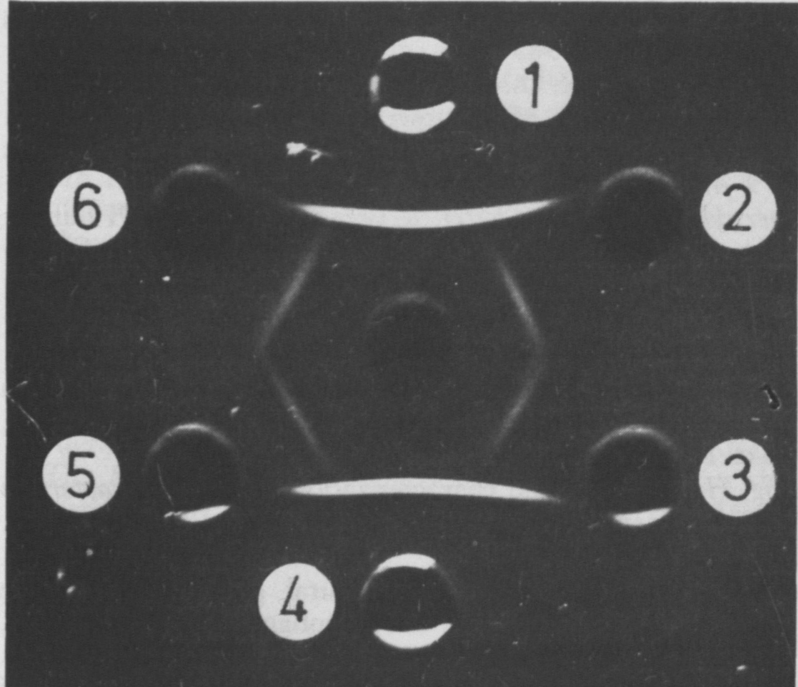

Fig. 8. Ouchterlony immunodiffusion test of antibodies against the DNA-dependent RNA polymerase of Sulfolobus acidocaldarius DSM 639. Purified or enriched RNA polymerases of $(1,4)$ S. acidocaldarius; (2) Sulfolobus-like isolate Kra23; (3) Metallosphaera sedula (isolate TH2); (5) A.brierleyi; (6) S. solfataricus.

ethers they resemble members of the genera Sulfolobus and Acidianus (De Rosa and Gambacorta, 1988). Due to their ore-leaching capacity and their ability to grow by oxidation of elemental sulfur and organic material, they are reminiscent of Acidianus brierleyi (Brierley and Brierley, 1973; Segerer et al., 1986). In contrast to A. brierleyi, the new isolates show a nearly round shape, grow at $80^{\circ} \mathrm{C}$ and tolerate $\mathrm{pH}$ values up to 5 . A further difference to all members of Acidianus is the inability of the isolates to grow anaerobically (Segerer et al., 1986). The new strains mobilize metal ions from sulfidic ores like chalcopyrite about 10 times faster than A. brierleyi and are therefore highly efficient ore leachers. In column leaching experiments on pyrite at $65{ }^{\circ} \mathrm{C}$, their metal extraction rate was around $1 \mathrm{~g} / \times \mathrm{d}$ which is more than 50 times higher than values of mesophilic metal-mobilizers e.g. Thiobacillus ferrooxidans ATCC 23270 at $30^{\circ} \mathrm{C}$ (G. Huber, H. Huber and K. O. Stetter, unpublished). Therefore, the new strains may be suitable for reactor leaching and for in situ leaching of geothermally heated ore deposits. Isolates $\mathrm{TH} 2$, TH4 and SP3a can be further distinguished from members of the genus Acidianus by a $14 \mathrm{~mol} \%$ higher GC-content of their DNA. Organisms with differences in the GC-content of more than $10 \%$ are usually believed to belong to different genera (Suoka, 1961; Bradley, 1971). By their strictly aerobic mode of life, the isolates resemble the two Sulfolobus species, S. acidocaldarius and S. solfataricus. Members of the genus Sulfolobus are characterized by their ability to oxidize elemental sulfur to sulfuric acid (Brock et al., 1972; Zillig et al., 1980). In contrast to the primary description, the type species S.acidocaldarius, represented by the type strain DSM 639, is unable to oxidize elemental sulfur and to form sulfuric acid (Huber and Stetter, unpublished). A similar result has been reported by Marsh et al. (1983) suggesting that the $S$. acidocaldarius type strain may have lost this property. In contrast to our new isolates, S. acidocaldarius and S. solfataricus are not able to grow on sulfidic ores and to mobilize metal ions. Strains TH2, TH4 and SP3a can be further distinguished from the Sulfolobus species by their inability to grow on sugars and their DNA not hybridizing with Sulfolobus. The incomplete cross-reaction of antibodies against the RNA polymerase of $S$.acidocaldarius with the enzyme of isolate TH2 indicates that the new strains are no members of the genus Sulfolobus (Stetter et al., 1981). Thermophilic organisms, growing on sulfur and yeast extract, with a GC-content similar to the new isolates have been reported by Furuya et al. (1977) and Golovacheva et al. (1987). These strains were not available to us and nothing is known about their taxonomic position and their ability to mobilize metal ions. Due to their morphology, physiology and biochemical characteristics, strains $\mathrm{TH} 2, \mathrm{TH} 4$ and SP3a represent a new genus, Metallosphaera, the "metal-mobilizing sphere". The three isolates share the same physiological properties and the DNA homologies between each other exceed $94 \%$. Therefore they are strains of the same species. In consequence of their strong ore-leaching activity, we name the new species Metallosphaera sedula. The type species is Metallosphaera sedula DSM5348. Like A. brierleyi (Brierley and Brierley, 1973), Metallosphaera sedula was isolated from a continental solfataric field. In their natural habitat, $\mathrm{H}_{2} \mathrm{~S}$ is present due to the volcanic activity ( $\mathrm{Hohl}$, 1985 ). With heavy metal ions, metal sulfides may be formed, which then serve as natural substrates for oreleaching bacteria. In accordance with this suggestion, numerous pyrite crystals (up to about $5 \mathrm{~mm}$ in length) were observed in the bluish-grey mud $\left(80^{\circ} \mathrm{C} ; \mathrm{pH} 4\right)$ of a solfataric field close to Cape Reykjanes, Iceland (K.O. Stetter, unpublished).

\section{Description of a novel genus and one new species}

Metallosphaera gen. nov. Me.tal.lo.sphae'ra. L. neut. n. metallum, ore; L. fem. n. sphaera, sphere; M.L. fem. n. Metallosphaera, the metal-mobilizing sphere.

Cells are regular to slightly irregular Gram-negative cocci, about 0.8 to $1.2 \mu \mathrm{m}$ in width. Growth between $50^{\circ} \mathrm{C}$ and $80^{\circ} \mathrm{C}$ (optimum around $75^{\circ} \mathrm{C}$ ) and $\mathrm{pH} 1.0$ to 4.5. Aerobic, facultatively chemolithoautotrophic. Lithotrophic growth on sulfidic ores like pyrite, sphalerite and chalcopyrite and on elemental sulfur. Production of sulfuric acid. No sulfur reduction by molecular hydrogen. Organotrophic growth on beef extract, casamino acids, peptone, tryptone and yeast extract, no utilization of sugars. Cell envelope composed of protein subunits, isopranyl ether lipids and caldariellaquinone in the cell membrane. ADP-ribosylation of an elongation factor II-like protein by diphtheria toxin. $45 \mathrm{~mol} \%$ GC-content of the DNA. DNA homology below $12 \%$ to the type strains of Acidianus infernus DSM 3191 and Sulfolobus acidocaldarius DSM 639. RNA polymerase exhibits the "BAC" type like the thermophilic sulfur metabolizing archaebac- 
teria and shows incomplete cross-reaction with antibodies against the enzyme of $S$. acidocaldarius. The molecular weights of the subunits are (in kilodaltons) 130, 104, 42, $33.5,32,24.5,15.8,14.5,13,11.8,11.3$ as determined by sodium dodecylsulfate polyacrylamide gel electrophoresis.

Metallosphaera sedula sp. nov., se'du.la. L. adj. sedulus, busy, describing the efficient metal mobilization. Description as for the genus.

Isolated from a continental solfataric field.

Type species is Metallosphaera sedula, TH2, DSM5348, Braunschweig, FRG

Acknowledgement. The excellent technical assistance of Lucia Schwarzfischer and Silvia Sur is greatly appreciated. We wish to thank F. Klink for providing unpublished data.

This work was supported by grants of the Bundesministerium für Forschung und Technologie (BMFT, Projektleitung Rohstoffforschung, Förderungskennzeichen $03 \mathrm{C} 1420$ and $03 \mathrm{R} 085 \mathrm{~A}$ 2 ) and by the Fonds der Chemischen Industrie.

\section{References}

Allen, M. B.: Studies with Cyanidium caldarium, an anomalously pigmented chlorophyte. Arch. Microbiol. 32, 270-277 (1959)

Balashova, V.V., Vedenina, I. Ya., Markosyan, G.E., Zavarzin, G. A.: The autotrophic growth of Leptospirillum ferrooxidans. Translated from: Mikrobiologiya 43, 581-585 (1974)

Bradley, S. G.: Criteria for definition of Mycobacterium, Nocardia and the rhodochrous complex. Advan. Front. Plant Sci. 28, 349-362 (1971)

Brierley, C.L., Brierley, J.A.: A chemoautotrophic and thermophilic microorganism isolated from an acid hot spring. Can. J. Microbiol. 19, 183-188 (1973)

Brierley, C. L., Murr, L. E.: Leaching: use of a thermophilic and chemoautotrophic microbe. Science 179, 488-490 (1973)

Brock, T.D., Brock, K.M., Belley, R.T., Weiss, R.L.: Sulfolobus: A new genus of sulfur-oxidizing bacteria living at low $\mathrm{pH}$ and high temperature. Arch. Microbiol. 84, 54-68 (1972)

Colmer, A. R., Hinkle, M. E.: The role of microorganisms in acid mine drainage: a preliminary report. Science 106, 253-256 (1947)

De Rosa, M., Gambacorta, A.: The lipids of archaebacteria. Prog. Lipid Res. 27, 153-175 (1988)

De Rosa, M., De Rosa, S., Gambacorta, A., Minale, L., Thomson, R.H., Worthington, R.D.: Caldariellaquinone, a unique benzo-b-thiophen-4,7-quinone from Caldariella acidophila, an extremely thermophilic and acidophilic bacterium. J. Chem. Soc. Perkin. Trans. 1, 653-657 (1977)

De Rosa, M., Gambacorta, A., Nicolaus, B., Chappe, B., Albrecht, $P$.: Isoprenoid ethers; backbone of complex lipids of the archaebacterium Sulfolobus solfataricus. Biochim. Biophys. Acta 753, 249-256 (1983 a)

De Rosa, M., Gambacorta, A., Nicolaus, B.: A new type of cell membrane in thermophilic archaebacteria, based on bipolar ether lipids. J. Memb. Sci. 16, 287-294 (1983 b)

Furuya, T., Nagumo, T., Itoh, T., Kaneko, H.: A thermophilic acidophilic bacterium from hot springs. Agric. Biol. Chem. 41, 1607-1612 (1977)

Golovacheva, R.S., Valiejo-Roman, K.M., Troitsky, A. V.: Sulfurococcus mirabilis gen. nov. sp. nov., a new thermophilic archaebacterium oxidizing sulfur. Mikrobiologiya 56, 100-107 (1987)
Hohl, R.: Die Entwicklungsgeschichte der Erde. Hanau, Verlag Werner Dausien 1985

Huber, H., Stetter, K. O.: Thiobacillus prosperus sp. nov., represents a new group of halotolerant metal-mobilizing bacteria isolated from a marine geothermal field. Arch. Microbiol. 151, 479-485 (1989)

Huber, H., Huber, G., Stetter, K. O.: A modified DAPI flurescence staining procedure suitable for the visualization of lithotrophic bacteria. System. Appl. Microbiol. 6, 105-106 (1985)

Kessel, M., Klink, F.: Archaebacterial elongation factor is ADPribosylated by diphtheria toxin. Nature 287, 250-251 (1980)

Kessel, M., Klink, F.: Identification and comparison of eighteen archaebacteria by means of the diphtheria toxin reaction. $\mathrm{Zbl}$. Bakt. Hyg., I. Abt. Orig. C 3, 140-148 (1982)

König, $H .:$ Isolation and characterization of Methanobacterium uliginosum sp. nov. from a marshy soil. Can. J. Microbiol. 30, 1477-1481 (1984)

Laemmli, U.K.: Cleavage of structural proteins during the assembly of the head of bacteriophage T4. Nature 227, 680-685 (1970)

Langworthy, T.A., Tornabene, T.G., Holzer, G.: Lipids of Archaebacteria. Zbl. Bakt. Hyg., I. Abt. Orig. C 3, 228-244 (1982)

Lanzotti, V., Trincone, A., Gambacorta, A., De Rosa, M., Breitmaier, E.: ${ }^{1} \mathrm{H}$ and ${ }^{13} \mathrm{C}$ NMR assignment of benzothiophenquinones from the sulfur-oxidizing archaebacterium Sulfolobus solfataricus. Eur. J. Biochem. 160, 37-40 (1986)

Marmur, J., Doty, P.: Determination of the base composition of deoxyribonucleic acid from its thermal denaturation temperature. J. Mol. Biol. 5, 109-118 (1962)

Marsh, R. M., Norris, P.R., Le Roux, N.W.: Growth and mineral oxidation studies with Sulfolobus, pp. 71-81. In: Recent progress in biohydrometallurgy (G. Rossi, A.E. Torma, eds.). Iglesias, Associazione Mineraria Sarda 1983

Mirault, M. E., Scherrer, K.: Isolation of preribosomes from Hela cells and its characterization by electrophoresis on uniform and expotential gradient polyacrylamide gels. Eur. J. Biochem. 23, 372-384 (1971)

Ouchterlony, Ö.: Diffusion-in-gel methods for immunological analysis II, pp. 30-154. In: Progress in allergy (P. Kallod, B. H. Waksman, eds.), Vol. VI. Basel, Karger 1962

Prangishvilli, D., Zillig, W., Gierl, A., Biesert, L., Holz, I.: DNAdependent RNA polymerases of thermoacidophilic archaebacteria. Eur. J. Biochem. 122, 471-477 (1982)

Schleifer, K. H., Stackebrandt, E.: Molecular systematics of prokaryotes. Ann. Rev. Microbiol. 37, 143-187 (1983)

Schnabel, R., Thomm, M., Gerardy-Schabn, R., Zillig, W., Stetter, K. O., Huet, J.: Structural homology between different archaebacterial DNA-dependent RNA polymerases analyzed by immunological comparison of their components. EMBO J. 2, 751-755 (1983)

Segerer, A., Neuner, A., Kristiansson, J.K., Stetter, K. O.: Acidianus infernus gen. nov., sp. nov., and Acidianus brierleyi comb. nov.: facultatively aerobic, extremely acidophilic thermophilic sulfur-metabolizing archaebacteria. Int. J. System. Bact. 36, 559-564 (1986)

Steigerwalt, A. G., Fanning, G. R., Fife-Asbury, M.A., Brenner, D. J.: DNA relatedness among species of Enterobacter and Serratia. Can. J. Microbiol. 22, 121-137 (1976)

Stetter, K. O.: Transcription in Lactobacillaceae: DNA-dependent RNA polymerase from Lactobacillus casei. Isolation of transcription factor y. Hoppe-Seyler's Z. phys. Chem. 358, 1093-1104 (1977)

Stetter, K. O., Thomm, M., Winter, J., Wildgruber, G., Huber, H., Zillig, W., Janécovic, D., König, H., Palm, P., Wunderl, S.: Methanothermus fervidus, sp. nov., a novel extremely ther- 
mophilic methanogen isolated from an Icelandic hot spring. Zbl. Bakt. Hyg., I. Abt. Orig. C 2, 166-178 (1981)

Suoka, N.: Variation and heterogeneity of base composition of deoxyribonucleic acids. A compilation of old and new data. J. Mol. Biol. 3, 31-40 (1961)

Thurl, S., Witke, W., Bubrow, I., Schäfer, W.: Different types of quinones from sulfur-dependent archaebacteria. Biol. Chem. Hoppe-Seyler 367, 191-197 (1986)

Trincone, A., De Rosa, M., Gambacorta, A., Lanzotti, V., Nicolaus, B., Harris, J. E., Grant, W. D.: A simple chromatographic procedure for the detection of cyclized archaebacterial glycerol-bisdiphytanyl-glycerol tetraether core lipids. J. Gen. Microbiol. 134, 3159-3163 (1988)

Wildgruber, G., Thomm, M., König, H., Ober, K., Ricchiuto, Th., Stetter, K. O.: Methanoplanus limicola, a plate-shaped methanogen representing a novel family, the Methanoplanaceae. Arch. Microbiol. 132, 31-36 (1982)
Williams, W.J.: Handbook of anion determination. London, Butterworths 1979

Woese, C. R., Magrum, L.J., Fox, G.E.: Archaebacteria. J. Mol. Evol. 11, 245-252 (1978)

Zillig, W., Stetter, K. O., Janékovic, D.: DNA-dependent RNA polymerase from the archaebacterium Sulfolobus acidocaldarius. Eur. J. Biochem. 96, 597-604 (1979)

Zillig, W., Stetter, K.O., Wunderl, S., Schulz, W., Priess, H., Scholz, I: The Sulfolobus "Caldariella" group: taxanomy on the basis of the structure of DNA-dependent RNA polymerases. Arch. Microbiol. 125, 259-269 (1980)

Zillig, W., Stetter, K.O., Schnabel, R., Madon, J., Gierl, A.: Transcription in Archaebacteria. Zbl. Bakt. Hyg., I. Abt. Orig. C 3, 218-227 (1982)

Prof. Dr. K. O. Stetter, Lehrstuhl für Mikrobiologie der Universität Regensburg, Universitätsstr. 31, D-8400 Regensburg, Federal Republic of Germany 


\title{
Nucleic Acid Hybridization Studies on Leuconostoc and Heterofermentative Lactobacilli and Description of Leuconostoc amelibiosum sp. nov.
}

\author{
ULRICH SCHILLINGER ${ }^{1}$, WILHELM HOLZAPFEL ${ }^{2}$, and OTTO KANDLER ${ }^{3}$
}

1 Bundesanstalt für Fleischforschung, E. C. Baumann-Str. 20, 8650 Kulmbach, Federal Republic of Germany

2 Bundesforschungsanstalt für Ernährung, Engesserstraße 20,7500 Karlsruhe 1, Federal Republic of Germany

3 Botanisches Institut der Universität München, Menzingerstraße 67, 8000 München 19, Federal Republic of Germany

Received January 20, 1989

\begin{abstract}
Summary
DNA-DNA and DNA-rRNA hybridizations were carried out with the type strains of all known Leuconostoc species and the taxonomically exceptional species of the heterofermentative lactobacilli which possess some phenetic characteristics unusual in lactobacilli but common in leuconostocs, e.g. particular chemotypes of peptidoglycan and slime formation. The results confirm the genomical relationship of the exceptional species of the heterofermentative lactobacilli with particular species of the genus Leuconostoc as well as the isolated position of the acidophilic species Leuconostoc oenos within the genus Leuconostoc.

Strains which have been tentatively named Leuconostoc mesenteroides subsp. "amelibiosum" were found to be only distantly related with any of the known Leuconostoc species and are described as Leuconostoc amelibiosum sp. nov.
\end{abstract}

Key words: Leuconostoc - Lactobacillus - Leuconostoc amelibiosum - Lactic acid bacteria - Nucleic acid hybridization - Relationship - Taxonomy - Peptidoglycan types

\section{Introduction}

Apart from its typically irregular coccoid morphology, the genus Leuconostoc is distinguished from the gas-forming heterofermentative lactobacilli mainly by two phenetic criteria: its inability to produce ammonia from arginine and the formation of only $\mathrm{D}(-)$-lactate from glucose ( $\mathrm{Gar}$ vie, $1984 ;$ 1986). However, some taxonomically exceptional species of the heterofermentative lactobacilli, such as Lactobacillus viridescens and Lactobacillus fructosus, do not hydrolyze arginine and form predominantly $\mathrm{D}(-)$ lactate. Moreover, the cell wall of such lactobacilli contains a peptidoglycan type similar to that of the leuconostocs (Kandler, 1970; Kandler and Weiss, 1986). In contrast with most heterofermentative lactobacilli, where the crosslinkage of the peptidoglycan subunits is mediated by an asparagine residue (L-Lys-D-Asp type), the amino acids alanine and serine are found to be typical constituents of the interpeptide bridge in the exceptional lactobacilli and in leuconostocs (Table 1). For instance, the peptidoglycan type of Leuconostoc mesenteroides (Lys-Ser- $\mathrm{Ala}_{2}$ ) was also found in Lactobacillus minor (Kandler et al., 1983) while L $b$. viridescens and Lactobacillus halotolerans contain the same type of peptidoglycan as Leuconostoc oenos (Lys-Ala-Ser) (Kandler et al., 1967). Some of the exceptional lactobacilli may share additional characteristics with leuconostocs, e.g. formation of very short coccoid rods, production of slime from sucrose, the same electrophoretic mobility or an immunological relatedness of various enzymes, such as pyruvate reductase (Sharpe et al., 1972), D(-)lactate dehydrogenase (Gasser and Gasser, 1971; Garvie, 1975), glucose-6-phosphate dehydrogenase (Gasser and Hontebeyrie, 1977). These findings indicate a specific relationship between the leuconostocs and the taxonomically exceptional heterofermentative lactobacilli.

This paper reports on DNA-DNA and DNA-rRNA hybridization studies among strains of the various species of Leuconostoc and some taxonomically exceptional heterofermentative lactobacilli. 